\title{
Pemberian Pakan Bentuk Cramble dan Mash Terhadap Produksi Ayam Petelor
}

\section{Feeding Crumble and Mash for Production of Laying Hens}

\author{
${ }^{1}$ Achmad Marzuki, Bahrur Rozi \\ Program Studi Produksi Ternak Jurusan Peternakan \\ Politeknik Negeri Jember \\ Jln Mastrip Kotak Pos 164 Jember \\ ${ }^{1}$ achmadmarzuki1955@gmail .com
}

\begin{abstract}
The purpose of this study is to determine the effect of feeding the form of crumble and mash on the production of laying hens from the pre layer phase. This research was conducted from November 11, 2015 to January 11, 2016, in laying chicken coop owned by Mr. Mahmud Kerajan Village Sumber Danti Village Sukowono District Jember District. The materials used in the study of laying pre layers (age 20 weeks) strains of Isa Brown, maize, concentrate, bran. Data analysis used was t test between (P1) chicken feed in the form of mash and (P2) chicken feed in with crumble form. The results showed that the feeding of Crumble form showed no significant difference to feed consumption ratio and feed egg ratio, and significantly different to HDP (Hen Day Production) laying hens. so it can be concluded that feeding of Crumble form can be given to increase egg production, giving advantage of difference of egg number during maintenance (age 20-28 weeks) that is 1213 grains
\end{abstract}

Keywords: Laying Hens, Crumble, Mash, Feed

\section{PENDAHULUAN}

Pertambahan jumlah penduduk yang semakin meningkat dan menciptakan masyarakat yang sehat harus diimbangi dengan pemenuhan kebutuhan gizi yang seimbang antara lain pemenuhan karbohidrat, vitamin, lemak, mineral dan protein. Berkaitan dengan kecukupan asupan protein dapat bersumber dari dua bahan yaitu sumber protein nabati misalnya sayuran dan protein hewani antara lain daging, susu dan telur.

Telur merupakan sumber protein hewani yang harganya relatif murah dan mudah diperoleh, sehingga sebagian masyarakat mengkonsumsi telur. Produksi telur ayam ras di Indonesia dari tahun 2007 - 2013 terus meningkat, yaitu dari 944.136 ton hingga
1.223.716 ton. Data peningkatan produksi telur ini membuktikan bahwa ternak ayam petelur merupakan usaha yang berpotensi untuk dikembangkan guna memenuhi kebutuhan protein hewani masyarakat Indonesia (Anonim, 2013).

Produksi telur akan maksimal jika ditunjang dengan manajemen pemeliharaan yang baik. Tiga aspek penting yang perlu diperhatikan dalam pemeliharaan yaitu bibit, pakan dan manajemen. Dari ketiga aspek tersebut, pakan memiliki proporsi terbesar yaitu $70 \%$ dari total biaya produksi.

Upaya yang dapat dilakukan untuk meningkatkan efisiensi pakan adalah menggunakan pakan dengan bahan dasar yang relatif murah, mudah diperoleh, dan kandungan nutrisi yang mencukupi 
serta didukung dengan pengolahan manipulasi bentuk pakan yang tepat. Peternak dapat menggunakana pakan dengan bentuk lain yang dapat diterapkan untuk meminimalisir tercecer pakan dan mengurangi sifat memilih pakan dari ayam, missalnya dengan menggunakan pakan bentuk crumble (butiran). Dari uraian diatas, untuk itu penelitian ini dilakukan untuk membandingkan hasil produksi telur yang lebih maksimal antara penggunaan pakan bentuk mash dan crumble.

\section{TINJAUAN PUSTAKA}

\subsection{Ayam Petelur}

Ayam layer atau ayam petelur adalah ayam yang diternakkan khusus untuk menghasilkan telur konsumsi. Jenis ayam petelur dibagi menjadi dua tipe yaitu tipe ayam ringan dan medium. Tipe ayam petelur ringan mempunyai badan yang ramping dan kecil, bulu berwarna putih bersih, dan berjengger merah, berasal dari galur murni White Leghorn, dan mampu bertelur lebih dari 260 butir telur pertahun, ayam petelur ringan sensitif terhadap cuaca panas dan keributan, responnya yaitu produksi akan menurun. Tipe ayam petelur medium memiliki bobot tubuh yang cukup berat, tidak terlalu gemuk, kerabang telur berwarna coklat, dan bersifat dwiguna (Bappenas, 2010). Ayam yang dipelihara sebagai penghasil telur konsumsi umumnya tidak memakai pejantan dalam kandangnya karena telur konsumsi tidak perlu dibuahi (Kartasudjan dan Suprijatna, 2006).

Produksi ayam dipengaruhi oleh banyak faktor, antara lain bangsa dan strain ayam yang digunakan, kondisi lingkungan dikandang, dan manajemen pakan (Bell dan Beaver, 2002; dikutip dalam Al Naseer et al.,2005).

\subsection{Pakan Ayam Petelur}

Bahan makanan untuk unggas disebut dengan pakan. Campuran bahan makanan atau pakan yang diberikan pada ayam disebut ransum. Ransum diartikan sebagai satu atau campuran beberapa jenis bahan pakan yang diberikan untuk seekor ternak selama sehari semalam (Manshur, 1998). Ransum adalah campuran berbagai macam bahan organic dan anorganik yang diberikan kepada ternak untuk memenuhi kebutuhan zat-zat makanan yang diperlukan bagi pertumbuhan, perkembangan, dan reproduksi. Agar pertumbuhan dan produksi maksimal, jumlah kandang zat-zat makanan yang diperlukan ternak harus memadai (Suprijatna et al., 2005).

Periode pertumbuhan ayam petelur dapat dibagi menjadi periode grower (umur $1-8$ minggu), developer (umur 8 - 16 minggu), dan prelay (umur 17 - 24 minggu). Kebutuhan nutrisi periode grower 18.6\% PK dan $3870 \mathrm{kkal} / \mathrm{kg}$ EM. Kebutuhan nutrisi periode pre-lay yaitu $18.0 \%$ PK dan $2755 \mathrm{kkal} / \mathrm{kg}$ EM (Al Nasser et al., 2005).

Jika energi pakan saat fase layer terlalu rendah (kurang dari $2600 \mathrm{kkal}$ ), konsumsi pakan lebih banyak sehingga FCR meningkat dan efisiensi pakan menurum. Sebaliknya jika energi pakan terlalu tinggi akan terjadi penurunan konsumsi (Harms et al., 2000). Kebutuhan PK dan EM pada fase layer tidak sama, tergantung dari umur ayam, produksi telur, dan konsumsi pakan.

\subsection{Mash (Tepung)}

Bentuk ini merupakan bentuk ransum yang umuim dilihat. Bahan yang dipilih menjadi ransum digiling halus kemudian dicampur menjadi satu. Ransum bentuk ini memiliki kelemahan mudah tercecer dan sifat memilih ayam karena pakan yang tidak halus, dan juga bentuk ransum ini memiliki keuntungan yaitu harganya lebih murah.

\subsection{Crumble (Butiran)}

Crumble merupakan tipe ransum yang dihasilkan dari campuran bahan pakan pada mesin pellet dan kemudian pellet dihancurkan dengan ukuran lebih kasar dari mash. Retnani et al., (2009) menyatakan bahwa pemberian pakan dalam bentuk crumble diharapkan dapat lebih menjamin campuran bahan pakan, termasuk bioaktif di dalam pakan lenbih homogen. Dengan demikian, bioaktif yang diberikan dalam pakan dapat dikonsumsi oleh ternak seluruhnya. Ransum bentuk crumble memberi hasil yang lebih baik karena bioaktif dapat tercampur secara homogen didalam pakan yang dikonsumsi. Menurut Kartadisastra (1994) menyatakan bahwa crumble memiliki spesifikasi seperti pakan tidak 
berdebu dan mudah untuk dikonsumsi, sehingga pakan yang disebabkan oleh aing sangat sedikit, bahan-bahan pakan penyusunnya sangat kompak dan tercampur merata, meningkatkan konsumsi pakan, relatif tidak mengandung bakteri membahayakan, pemborosan pakan (akibat hilang) dapat ditekan dan formula pakan menjadi lebih efisien.

\subsection{Konsumsi Pakan}

Konsumsi pakan merupakan jumlah pakan yang dikonsumsi oleh ternak dalam bentuk tertentu guna memenuhi kebutuhan hidup (Rasyaf, 1982). Faktor- faktor yang mempengaruhi konsumsi pakan ayam adalah kesehatan ayam, kandungan energi dalam ransum, macam bahan pakan, kondisi ransum yang diberikan, kebutuhan produksi, selera dan metode pemberian pakan yang digunakan (Rasyaf, 1993).

\subsection{Feed Egg Ratio (FER)}

FER merupakan hasil dari perbandingan antara ransum yang dikonsumsi pada waktu tertentu dengan jumlah telur pada waktu tertentu pula yang dicapai untuk menilai efisiensi pakan. Semakin kecil angka konversi maka semakin efisiensi penggunaan ransum (Anggorodi, 1995

\subsection{Produksi Telur}

Produksi telur adalah upaya untuk memadukan sumber daya terpilih agar menghasilkan telur (Rasyaf, 1991). Dalam produksi telur ternak membutuhkan makanan, ketenangan, dan kesehatan. Untuk kebutuhan hidupnya, unggas menbutuhkan sejumlah unsur-unsur gizi seperti protein, energi, vitamin, mineral, dan air. Bila dibutuhkan pokok sudah terpenuhi, maka selebihannya baru digunakan untuk kebutuhan produksi pembentukan telur.

Produksi telur dinyatakan dalam HDP. Hen Day Production (HDP) merupakan presentase produksi telur dalam jangka waktu tertentu. Cara menghitung produksi harian adalah jumlah telur dibagi jumlah ayam saat ini dikali $100 \%$ biasa dihitung selama 1 minggu (Trenggono, 2014).

\section{METODOLOGI}

Penelitian ini dilakukan di peternakan ayam petelur Bapak Mahmud, Desa Sumberdanti Kecamatan Sukowono Kabupaten Jember bulan Oktober 2015 sampai Januari 2016.
Alat yang digunakan berupa kandang batere, recording, lampu tempat minum, tempat pakan, dan timbangan.

Bahan yang digunakan adalah 400 ekor ayam petelur strain Isa Brown umur 18 minggu, pakan ayam petelur bentuk Mash (tepung), Crumble (butiran), vaksin, vitamin dan air.

Metode penelitian ini adalah percobaan dengan membandingkan dua perlakuan. Ayam petelur umur 18 minggu sebanyak 400 ekor dan dibagi 2 perlakuan satu perlakuan terdiri 200 ekor yang ditempatkan secara acak pada 10 petak, setiap petak terdiri dari 40 ekor ayam dengan berat badan awal penelitian yang homogen. Perlakuan diberikan pada ayam umur 19 sampai 28 minggu. Metode pengujian dalam penelitian ini adalah menggunakan uji t :

1. $\mathrm{P} 1$ = pakan bentuk mash, 2. $\mathrm{P} 2=$ pakan bentuk crumble

Parameter yang diamati adalah : Konsumsi Pakan (g), Hen Day Production (\%), dan Feed Egg Ratio.

\section{HASIL DAN PEMBAHASAN \\ 4.1 Konsumsi Pakan}

Data rataan konsumsi pakan ayam petelur dengan pemberian pakan bentuk crumble (butiran) dan bentuk mash (tepung) disajikan dalam Tabel 4.1.

TABEL 4.1 RATAAN KONSUMSI PAKAN AYAM

PETELUR STRAIN ISA BROWN UMUR 19 - 28 MINGGU

(GRAM/EKOR)

\begin{tabular}{cccc}
\hline \multirow{2}{*}{ Ulangan } & \multicolumn{2}{c}{ Rataan Konsumsi Pakan } & T tabel \\
\cline { 2 - 3 } & Mash $(\mathrm{P} 2)$ & $\begin{array}{c}\text { Crumble } \\
(\mathrm{P} 1)\end{array}$ & \\
\hline 1 & 89,71 & 89,71 & \\
2 & 89,71 & 89,71 & \\
3 & 89,72 & 89,73 & \\
4 & 89,72 & 89,71 & \\
5 & 89,72 & 89,75 & \\
\hline Jumlah & 448,58 & 448,61 & \\
\hline Rata- & 89,716 & 89,722 & \\
rata & & & 2,31 \\
\hline Uji t & t hitung $=0,92$ &
\end{tabular}

Ket : $\quad$ Hasil analisis, bentuk pakan tidak berbeda nyata $(\mathrm{t}$ hitung $<\mathrm{t}$ tabel 5\%) terhadap konsumsi pakan 
Perlakuan bentuk pakan yang tidak berbeda nyata dibandingkan kontrol terhadap jumlah pakan yang dikonsumsi oleh ayam petelur memberikan penjelasan bahwa pemberian pakan dalam bentuk crumble (butiran) membuat ayam terus mengkonsumsi pakan sampai habis hingga kebutuhan energi ayam terpenuhi sama halnya dengan kontrol hanya untuk kelangsungan hidup ayam. Sesuai dengan pendapat Rasyaf (1997) ayam makan untuk memenuhi kebutuhan akan energinya, ayam harus bergerak dan menjalankan fungsi-fungsi tubuh lainnya yang semuanya memerlukan tenaga dari energi yang diperoleh dari makanan. Konsumsi pakan ayam layer pada fase starter yaitu $1,08 \pm 0,05 \mathrm{~kg}$ per ekor pada fase grower yaitu $4,14 \pm 0,11 \mathrm{~kg}$ per ekor, pada fase layer yaitu 31,2 $\pm 1,12 \mathrm{~kg}$ per ekor (Mussawar et al., 2004). Konsumsi pakan dipengaruhi oleh strain, umur, keseimbangan nutrisi pakan, status kesehatan ayam, keterjangkauan pakan oleh ayam, dan temperature lingkungan (Iji, 2005).

\subsection{Hen Day Production (HDP)}

Rata - rata Hen Day Production (HDP) ayam petelur dengan pemberian pakan bentuk crumble (butiran) dan bentuk mash (tepung) disajikan dalam Tabel 4.2.

\begin{tabular}{|c|c|c|c|}
\hline \multicolumn{4}{|c|}{$\begin{array}{r}\text { TABEL 4.2 RATAAN HEN DAY PRODUCTION AY } \\
\text { ISA BROWN UMUR } 28 \text { MINGGU }\end{array}$} \\
\hline \multirow{2}{*}{ Ulangan } & \multicolumn{2}{|c|}{ Rataan Produksi telur(\%) } & \multirow[t]{2}{*}{$\mathrm{T}$ tabel } \\
\hline & Mash & Crumble & \\
\hline 1 & 81,43 & 81,79 & \\
\hline 2 & 73,93 & 78,93 & \\
\hline 3 & 78,57 & 83,57 & \\
\hline 4 & 81,07 & 86,79 & \\
\hline 5 & 78,21 & 88,93 & \\
\hline Jumlah & 393,2 & 420 & \\
\hline Rata-rata & 78,64 & 84 & \\
\hline Uji t & \multicolumn{2}{|c|}{ t hitung $=2,414$} & 2,31 \\
\hline Ket : & $\begin{array}{l}\text { analisis } \\
>\mathrm{t} \text { tabe }\end{array}$ & $\begin{array}{l}\text { pakan b } \\
\text { rhadap } H\end{array}$ & $\begin{array}{l}\text { myata }(\mathrm{t} \\
\text { roduction }\end{array}$ \\
\hline
\end{tabular}

Hen Day Production (HDP) yang berbeda nyata disebabkan pakan bentuk crumble (butiran) bahan-bahan pakan lebih tercampur merata (homogen). Sebagai dengan pendapat Rasyaf (1997) ransum ayam ras berbentuk "butiran" atau bentuk "pellet" yang dalam satu butir mengandung semua unsur yang dibutuhkan oleh ayam. Dan juga dengan bentuk pakan crumble (butiran) lebih cepat habis dibandingkan pakan bentuk mash (tepung), otomatis energi yang dikeluarkan untuk mengkonsumsi pakan crumble lebih sedikit dari pada memakan pakan bentuk tepung yang harus mengeluarkan energi ekstra. Rasyaf (1997) ayam makan untuk memenuhi kebutuhan akan energinya, ayam harus bergerak dan menjalankan fungsi-fungsi tubuh lainnya yang semuanya memerlukan tenaga dari energi yang diperoleh dari makanan. Jadi sisa waktu mengkonsumsi pakan dapat dimaksimalkan untuk menjalankan fungsi-fungsi tubuh lainya (produksi telur).

\subsection{Feed Egg Ratio (FER)}

Data rataan Feed Egg Ratio ayam petelur dengan pemberian pakan bentuk crumble (butiran) dan bentuk mash (tepung) disajikan dalam Tabel 3.3.

TABel 3.3. RataAn FER Ayam Petelur Strain ISA BROWN UMUR 28 MINGGU

\begin{tabular}{cccc}
\hline \multirow{2}{*}{ Ulangan } & \multicolumn{2}{c}{ Konversi Pakan } & T tabel \\
\cline { 2 - 3 } & Mash $(\mathrm{P} 1)$ & $\begin{array}{c}\text { Crumble } \\
(\mathrm{P} 0)\end{array}$ & \\
\hline 1 & 2,083 & 2,127 & \\
2 & 2,254 & 2,175 & \\
3 & 2,131 & 2,084 & \\
4 & 2,080 & 2,045 & \\
5 & 2,147 & 2,013 & \\
\hline Jumlah & 10,698 & 10,447 & 2,31 \\
\hline Rata- & 2,139 & 2,089 & \\
rata & \multicolumn{2}{c}{ t hitung $=1,17$} \\
\hline Uji t &
\end{tabular}

Ket : Hasil analisi, bentuk pakan tidak berbeda nyata ( $\mathrm{t}$ hitung $<\mathrm{t}$ tabel, 5\%) terhadap FER.

Tidak adanya perbedaan yang nyata antar perlakuan diduga disebabkan tingkat konsumsi pakan dan pertambahan bobot hidup yang dicapai pada masingmasing perlakuan hampir sama. Tinggi rendahnya nilai konversi pakan sangat dipengaruhi oleh konsumsi ransum dan pertambahan bobot badan harian (Zahra $e t$ al., 2012 dalam Widodo, 2013). Ayam petelur yang baik akan makan sejumlah ransum dan menghasilkan telur yang lebih banyak daripada sejumlah ransum yang dimakan (Bappenas, 2010). 
FCR ayam layer umumnya sebesar 2,33 $+0,04$ (Mussawar, 2004)

Pada Tabel 3.3 menunjukkan bahwa FER yang rendah ada pada P1 diduga karena konsumsi pakan rendah dan pertambahan bobot badan yang lebih tinggi dibandingkan P2. Sesuai dengan pendapat Rasyaf, M (2001) Angka konversi tinggi menunjukkan penggunaan ransum kurang efisien, sebaliknya jika angka mendekati satu berarti penggunaan pakan semakin efisien.

Jadi penggunaan pakan dalam bentuk crumble tidak mempengaruhi konsumsi pakan dan FER ayam petelur, tetapi mempengaruhi produksi harian atau Hen Day Production (HDP) ayam petelur. Dimana terlihat perbedaan produksi telur pada awalawal periode yaitu pada minggu ke-1 sampai dengan minggu ke-5 pemeliharaan. Total produksi telur dengan aplikasi pemberian pakan bentuk crumble yaitu 6051 butir atau 315,6 kg dan total produksi telur yang menggunakan pakan bentuk mash yaitu 4838 butir atau $255,5 \mathrm{~kg}$ selama pemeliharaan. Jadi selisih produksi telur antara penggunaan pakan crumble dan mash yaitu 1213 butir atau 60,1 kg. Jika dirupiah diperoleh keuntungan Rp. 1.081.800,- dan dikurangi biaya transport, biaya pembuatan pakan crumble dengan total Rp. 429.500,-. Jadi diperoleh seluruh pendapatan sebesar Rp. 652.300,- dengan penggunaan pakan bentuk crumble selama pemeliharaan (umur 2028 minggu).

\section{KESIMPULAN DAN SARAN \\ 4.1.Kesimpulan}

Pemberian pakan bentuk crumble tidak berpengaruh terhadap konsumsi pakan dan FER (Feed Egg Ratio), namun berpengaruh terhadap HDP (Hen Day Production) ayam petelur. Dalam hasil analisis usaha menunjukkan bahwa pemberian pakan crumble memberikan keuntungan sebesar Rp. 652.300,-.

\subsection{Saran}

Disarankan peternak menggunakan pakan bentuk crumble guna meningkatkan Hen Day Production ayam petelur.

\section{DAFTAR PUSTAKA}

[1] Anggorodi, R. 1985. Ilmu Makanan Ternak Umum. Gramedia, Jakarta.
[2] Anggorodi, H. S., 1995. Nutrisi Aneka Ternak Unggas. PT. Gramedia Pustaka Utama. Jakarta.

[3] Al Nasser, A. A. Al Saffar, M. Mashaly, H. Al. Khalaifa, F. Khalil, M. Al Baho, Dana. Al Haddad. 2005. A Comparative Study On Production Efficiency Of Brown And White Pullet. Bulletin Of Kuwait Institute For Scientific Research 1 (1): 1-4

[4] Baan pusat statistic. 2013. "rata-rata konssumsi kalori (kkal) perkapita sehari”. http://www.bps.go.id

[5] Bappenas. 2010. Beternak Ayam Petelur. http.//www.ristek.go.id. Diakses tanggal 5 mei 2010 pk. 13.57 .

[6] Blakely, j. dan d.h. bade. 1998. Ilmu peternakan. Gadjah mada university press, Yogyakarta (diterjemahkan oleh b. srigandoro).

[7] Harm, R.H., G.B. Russel, dan D.R. Sloan. 2000. Performance Of Four Strains Pf Commercial Layer With Major Changes In Dietary Energy. Journal Of Applied Poultry Research 9: 535 - 541

[8] Hy-Line International. 2010. Hy-Line Brown Intensive Systems Performance Standards. http://www.hyline.com/redbook/performance. Diakses tanggal 16 januari 2011 pk. 15.57 .

[9] Iji, P. 2005. Feed Intake. http://www.poultryhub.org/index.hph/feed_intake. diakses tanggal 29 Maret 2010 pk 18.56.

[10] Kartasudjana, R. Dan E. Suprijatna. 2006. Manajemen Ternak Unggas. Penebar Swadaya, Jakarta.

[11] Miles, R.D Dan J.. Jacob. 2009. Using Meat And Bone Meal In Poultry Diet. University of Florida, Florida

[12] Mussawar, S., T.M. Durrani, K. Munir, Z. ul-Haq, M.T. Rahman, dan K.Sarbiland. 2004. Satatus of layer farms in peshawardivision, Pakistan. Livestock research for rural Development 16 (5) : 25 - 27

[13] Kartadisastra, H. R. 1994. Pengelolaan Pakan Ayam. Kanisius. Yogyakarta.

[14] Pritchard, S. 2005. Using Egg Mass As A Tool. http://www.questia.com/journals.diakses tanggal 29 maret 2010 pk. 18.34 .

[15] Rasyaf. M, 1991. Pengelolaan Produksi Telur. Penerbit Kanisius, IPB. Bogor

[16] Rasyaf, 1990, Beternak Ayam Petelur, Penebar Surabaya, Jakarta.

[17] Rasyaf, 1992, Produksi Dan Pemberian Ransum Unggas, Kanisius, Yogyakarta

[18] Retnani Yuli, L. Herawati dan S. Khusniati. 2011. Uji Sifat Fisik Ransum Broiler Starter Bentuk Crumble Berperekat Tepung Tapioka, Bentonit dan Onggok.JITPVol.1No.2http://www.alatpengemas.com 
Achmad Marzuki, Bahrur Rozi. Pemberian Pakan Bentuk Cramble dan Mash Terhadap Produksi Ayam Petelor

[19] Tilman , D. A., H. Hartadi, S. Prawiro dan Lebdosoekodjo. 1989. Ilmu Makanan Ternak Dasar. Gadjah Mada University Press. Yogyakarta.

[20] Widodo, A. R., H. Setiawan, Sudiyono, Sudibya dan R. Indreswari. 2013. Kecernaan Nutrien dan Performan Puyuh (Coturnix coturnix japonica) Jantan yang Diberi Ampas Tahu Fermentasi dalam Ransum. Dalam Tropical Animal Husbandry Vol 2 (1), Januari 2013. Hlm. 51-57 